\title{
MEMPERSIAPKAN PILKADA YANG AMAN DAN SEHAT DI ERA PANDEMIC COVID-19
}

DOI: https://doi.org/10.33024/jkpm.v4i4.4013

\section{Ayu Dewi Nastiti}

Universitas Jember Kampus Kota Pasuruan

Disubmit: 12 Maret 2021 Diterima: 07 April 2021 Diterbitkan: 03 Agustus 2021

Email: ayudewi.akper@unej.ac.id

\begin{abstract}
ABSTRAK
Pemilihan kepala Daerah atau Pilkada adalah wujud demokrasi dan Hak Asasi Manusia (HAM). Pemilihan kepala daerah pada tahun ini sangatlah berbeda dari Pilkada-Pilkda sebelumnya, dikarenakan ini pertama kalinya dilaksanakan Pemilihan Kepala Daerah di tengah - tengah pandemi Covid-19. Berdasarkan keputusan yang sudah ditetapkan oleh pemerintah, tentunya pemerintah harus juga memikirkan terhadap resiko terburuk yang akan terjadi, yaitu kasus covid19 akan semakin meningkat. Untuk itu perlu adanya strategi yang harus dilaksakan selama pelaksanaan pilkada. Melalui Penyuluhan tentang covid-19 dan cara memutus mata rantai penyebarannya diharapkan pengetahuan masyarakat khususnya bagi petugas pilkada meningkat, mengingat petugas pilkada akan berinteraksi dengan banyak orang saat pelaksanaan pilkada, sehingga pelaksanaan Pilkada bisa berjalan aman dan sehat. Hasil evaluasi sebagian besar peserta (90\%) memahami dan mengerti tentang materi yang disampaikan. Peserta senang dengan penyuluhan ini, hal ini terbukti dengan banyaknya peserta yang aktif dalam diskusi dan mengajukan pertanyaan serta antusias ketika pelaksanaan diskusi.
\end{abstract}

Kata Kunci : Pilkada, Petugas Pilkda, Covid-19

\section{ABSTRACT}

The democratic party for the Regional Head Election or better known as the Pilkada is the manifestation of democracy and human rights (HAM). This year's regional head elections are very different from the previous Pilkada-Pilkda, because this is the first time a Regional Head Election has been held in the midst of the Covid-19 pandemic. Based on the decision that has been set by the government, of course the government must also think about the worst risk that will occur, namely the covid-19 case will increase. For this reason, it is necessary to have a strategy that must be implemented during the implementation of the elections. Through counseling about covid-19 and how to break the chain of distribution it is hoped that public knowledge, especially for election officials, will increase, considering that pilkada officers will interact with many people during the election, so that the implementation of the Pilkada can run safely and healthily. The results of the evaluation, most of the participants (90\%) understood and understood the material presented. The participants were 
happy with this counseling, this was proven by the many participants who were active in the discussion and asked questions and were enthusiastic during the discussion.

Keywords: Pilkada, Pilkda Officer, Covid-19

\section{PENDAHULUAN}

Pemilihan kepala Daerah atau Pilkada adalah wujud demokrasi dan Hak Asasi Manusia (HAM). Pemilihan kepala daerah pada tahun ini sangatlah berbeda dari Pilkada-Pilkda sebelumnya, dikarenakan ini pertama kalinya dilaksanakan Pemilihan Kepala Daerah di tengah - tengah pandemi Covid-19. Pandemi Covid-19 berdampak signifikan dan memberikan tekanan di berbagai wilayah negara untuk memutuskan apakah Pemilu atau Pilkada (di tingkat lokal) dapat berlangsung atau tidak sehingga hal tersebut menuai kontroversi. Dua pilihan yang dilematis yaitu pemenuhan kontak sosial antara pemerintah dengan masyarakat atau meningkatnya kasus positif Covid-19 akibat dari berkumpulnya massa karena mengikuti Pilkada (Spinelli, 2020). Untuk menyikapi hal tersebut Menteri Dalam Negeri, DPR, KPU, Bawaslu, dan DKPP sepakat menunda penyelenggaraan Pilkada 2020. Opsi penundaan Pilkada yaitu 9 Desember 2020, 17 Maret 2021 dan 29 Desember 2021. PP Nomor 2 Tahun 2020 kemudian menetapkan pilihan pertama yaitu 9 Desember 2020 sebagai tanggal pelaksanaan Pilkada 2020. Berdasarkan keputusan yang sudah ditetapkan oleh pemerintah, tentunya pemerintah harus juga memikirkan terhadap resiko terburuk yang akan terjadi, yaitu kasus covid-19 akan semakin meningkat. Untuk itu perlu adanya strategi yang harus dilaksakan selama pelaksanaan pilkada (Hergianasari, 2020 ).

Coronavirus merupakan jenis virus yang menyebabkan penyakit yang menimbulkan gejala ringan sampai berat. Diketahui ada dua jenis Corona Virus penyebab penyakit yang menimbulkan gejala berat seperti Middle East Respiratory Syndrome (MERS) dan Severe Acute Respiratory Syndrome (SARS). Coronavirus Disease 2019 (COVID-19) merupakan jenis penyakit baru yang selama ini belum pernah teridentifikasi pada manusia. Virus penyebab COVID19 ini dinamakan SarsCoV-2. Dalam rentang waktu yang cukup singkat Penambahan jumlah kasus COVID-19 berlangsung cukup cepat dan sudah terjadi penyebaran antar negara (Kemenkes, 2020). Jumlah kasus positif virus Corona COVID-19 pada 21 November 2020 bertambah 4.998 kasus. Total positif menjadi 493.308, sembuh 413.955, dan meninggal 15.774 (Dinas Kominfo,2020)

Kabupaten Mojokerto merupakan salah satu daerah yang juga akan melaksanakan pilkada. Tentunya juga menjadi tantangan bagi pemerintah Kabupaten Mojokerto agar pemilu berjalan secara aman dan sehat di era pandemic covid-19 ini. Protokol Kesehatan harus benar-benar dilaksanakan secara ketat agar tidak terjadi penyebaran covid-19 selama pelaksanaan pilkada. Perlu pengetahuan tentang covid-19 terkait bagaimana memutus mata rantai penyebarannya terutama selama pelaksanaan pilkada.

Melalui kegiatan pengabdian masyarakat ini diharapkan pengetahuan masyarakat khususnya bagi petugas pilkada meningkat, mengingat petugas pilkada akan berinteraksi dengan banyak orang saat pelaksanaan pilkada. 


\section{MASALAH}

Petugas Pilkada merupakan garda terdepan dalam pelaksanaan Pilkada, dimana kerentana untuk tertular covid-19 juga lebih tinggi, mengingat petugas pilkada akan berinteraksi dengan banyak orang. Untuk itu sasaran kelompok penyuluhan yang dipilih adalah petugas pilkada. Kabupaten Mojokerto merupakan salah satu daerah yang melaksanakan pilkada serentak pada 09 Desember 2020, untuk itu sebelum pelaksanaan pilkada perlu dilakukan sosialisasi untuk memutus mata rantai penyebaran covid-19, selain itu kasus covid-19 di Kabupaten Mojokerto juga masih tinggi.

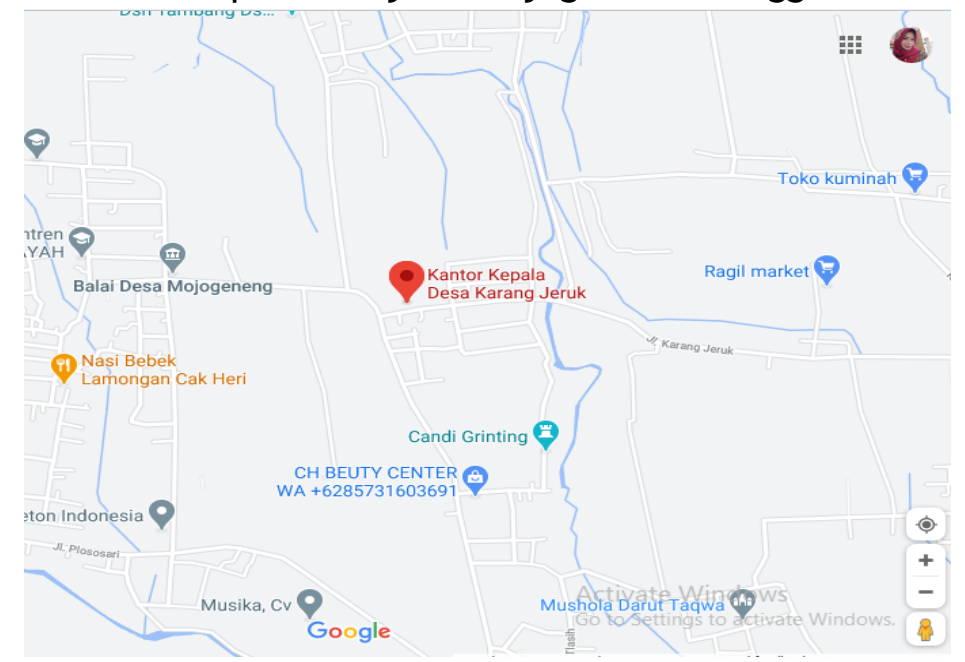

Gambar 1. Desa Karangjeruk Kabupaten Mojokerto

\section{METODE}

Subjek dalam kegiatan ini adalah seluruh petugas Pilkada di wilayah Desa Karangjeruk. Lokasi ini dipilih mengingat wilayah ini masuk ke dalam Zona Merah di Wilayah Kabupaten Mojokerto. Tahap persiapan dilakukan dengan melakukan koordinasi dengan Perangkat Desa setempat terkait dengan akan diselenggrakannya kegiatan pengabdian ini, mengidentifikasi kebutuhan sumber daya selama kegiatan, dan mempersiapkan segala kebutuhan kegiatan dengan dibantu oleh mahasiswa Prodi D3 Keperawatan Unej Kampus Kota Pasuruan.

Tahap Implementasi yaitu memilih strategi komunikasi yang efektif untuk pelaksaaan kegiatan, teknik ceramah dipilih karena dianggap paling efektif untuk meningkatkan pengetahuan masyarakat, selain itu juga digunakan teknik diskusi dimana diharapkan masyarakat bisa saling bertukar pikiran. Kegiatan ini dilakukan dilakukan secara luring akan tetapi dengan mematuhi protocol kesehatan,. Sebelum dimulai kegiatan terlebih dahulu dijelaskan maksud dan tujuan dilakukan kegiatan penyuluhan. Kegiatan pelatihan ini dibuka oleh kepala Desa Karangjeruk dilanjutkan dengan perkenalan dan penyampaian materi. Dalam pelaksanaan kegiatan ini menggunakan media LCD untuk pemaparan teori terkait covid-19 secara umum dan bagaimana cara memutus mata rantai penyebarannya dilanjutkan dengan sesi diskusi. 


\section{HASIL DAN PEMBAHASAN}

Kegiatan ini berlangsung selama 1 hari dan diikuti oleh seluruh petugas pilkada di Desa Karangjeruk sebanyak 25 orang. Kegiatan diawalai dengan sambutan oleh Kepala Desa dan perwakilan dari Prodi D3 Keperawatan Unej Kampus Kota Pasuruan, setelah sesi sambutan kemudian dilanjutkan dengan pemateri memberikan materi terkait dengan Covid-19 melalui media power point, kemudian pemateri menampilkan video terkait protocol kesehatan.sebelum pemaparan materi pemateri terlebih dahulu melakukan pre test secara lisan, yaitu dengan menanyakan beberapa hal terkait dengan Covid-19 misalnya tentang definisinya, gejalanya, penyebarannya, dalam pre test terlihat bahwa peserta tidak begitu paham dengan Covid-19 hal itu terbukti dengan peserta salah menjawab terkait dengan pertanyaan yang disampaikan. Setelah penyampaian materi dilanjutkan sesi Tanya jawab oleh peserta. Dalam sesi diskusi peserta cukup bersemangat dalam memberikan pertanyaan, banyak pertanyaan yang disampaikan oleh peserta seputar Covid19.

Setelah sesi diskusi pemateri malakukan post tes secara lisan kepada peserta, dalam post tes yang dilakukan peserta mampu menjawab pertanyaan yang disampaikan oleh pemateri dengan benar.

Seperti yang disampaikan oleh Shalahudin Iwan (2021) dimana metode ceramah sangat efektif untuk mempermudah peserta dalam memahami isi dan materi yang disampaikan. Selain dengan ceramah metode Tanya jawab merupakan salah satu usaha untuk menyingkirkan rintangan selama proses ceramah.

Efektifitas metode yang digunakan oleh pemateri yaitu ceramah dan diskusi cukup terlihat, terbukti dengan sebagian besar peserta (90\%) memahami dan mengerti tentang materi yang disampaikan. Peserta senang dengan penyuluhan ini, hal ini terbukti dengan banyaknya peserta yang aktif dalam diskusi dan mengajukan pertanyaan serta antusias ketika pelaksanaan diskusi. Berikut gambar pelaksanaan kegiatan:

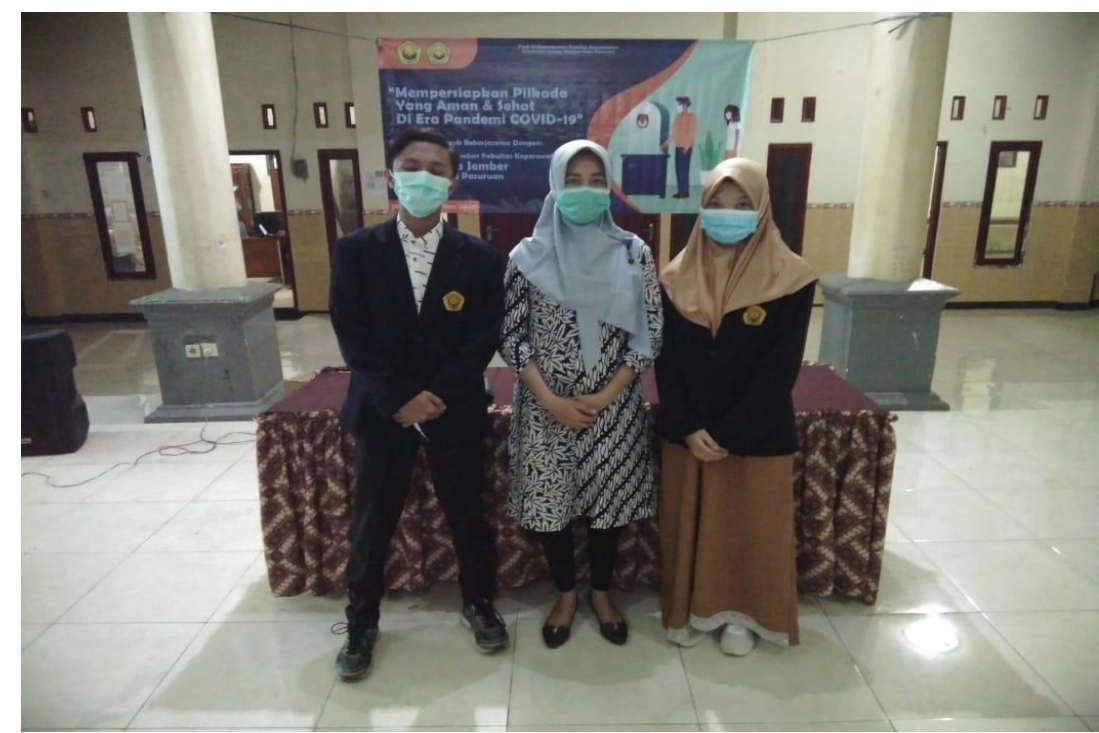

Gambar 2. Foto Bersama Panitia 


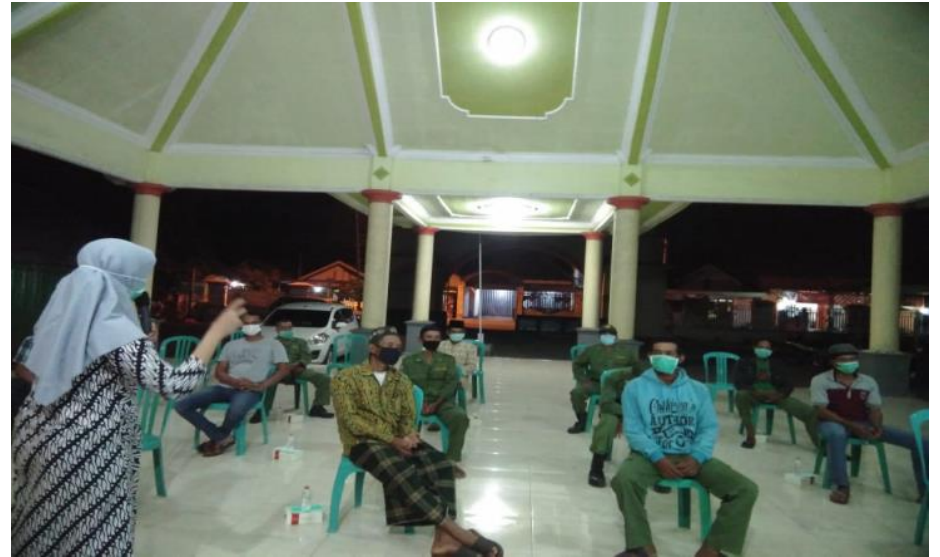

Gambar 3. Foto Narasumber Saat Menyampaikan Materi

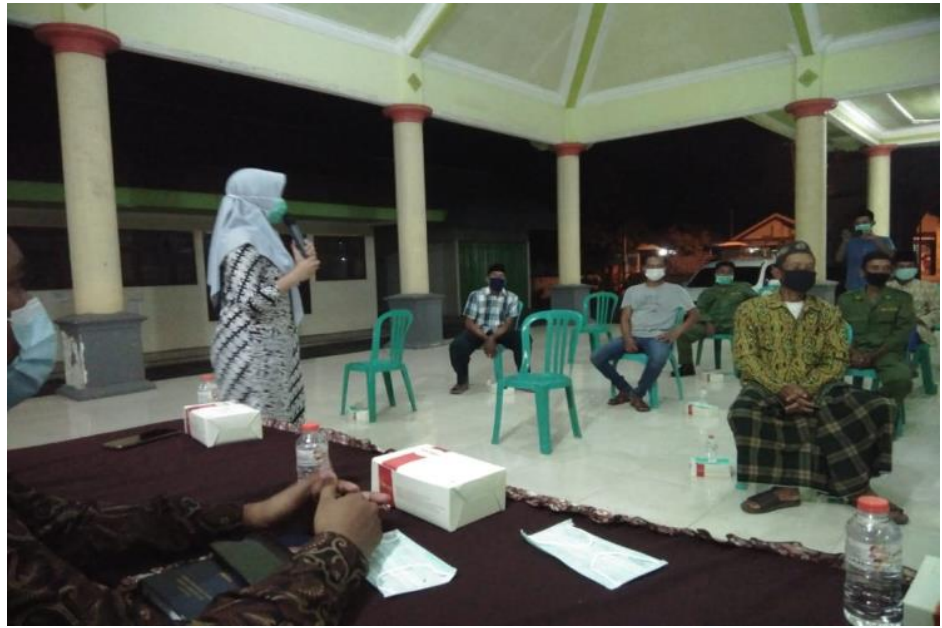

Gambar 4. Foto Narasumber saat menyampaikan Materi

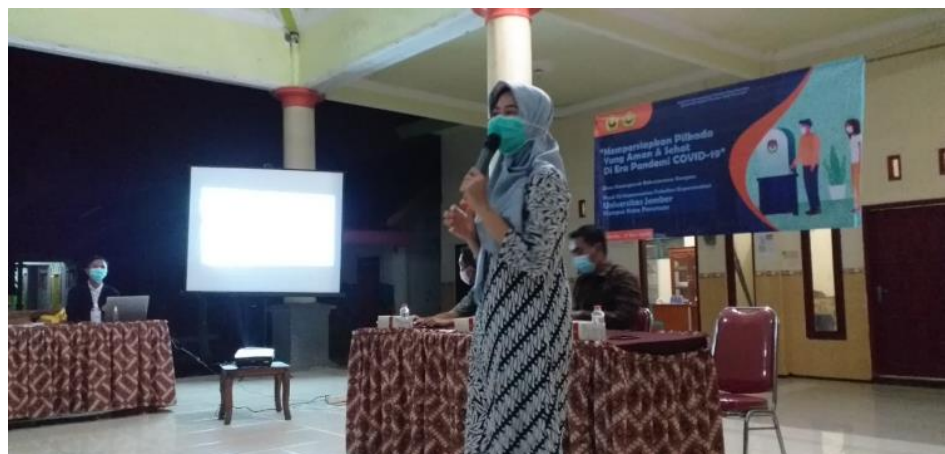

Gambar 5. Foto Narasumber saat menyampaikan Materi

\section{KESIMPULAN}

Kesimpulan yang bisa ditarik dari kegiatan ini seluruh peserta cukup aktif dalam kegiatan ini dan tidak meninggalkan tempat sampai acara selesai. Perubahan peningkatan pengetahuan peserta mengenai covid-19 dan cara memutus mata rantai penyebarannya di ukur dengan hasil apersepsi dan evaluasi, terjadinya peningkatan pemahaman tentang covid-19 dan cara memutus mata rantai penyebarannya. 


\section{DAFTAR PUSTAKA}

Agustin. F. (2021). Penyuluhan Tentang Pentingnya Mematuhi Protokol Kesehatan Di Era Pandemi Covid-19 Di Upt Puskesmas Kampung Sawah Bandar Lampung. Jurnal Kreativitas Pengabdian Kepada Masyarakat (PKM), 4 (1), 207-212,DOI: https://doi.org/10.33024/jkpm.v4i1.3673.

Dinas Komlnfo Jatim. Jatim Tanggap Covid19 Jatim Self Assessment. http: / /www.kominfo.jatimprov.go.id/. (Diakses November 10, 2020)

Ertiana, D., Ulfa, M., Aspiyani., Silaturrokhmah., \& Prastiwi, N.W.Y. (2020). Peningkatan Peran Serta Masyarakat Dalam Pencegahan Covid-19 di Desa Maduretno Kecamatan Papar Kabupaten Kediri. Darmabakti: Pengabdian dan Pemberdayaan Masyarakat, 1 (2), 23-33, DOI: https://doi.org/10.31102/darmabakti.2020.1.2.23-33.

Hergianasari, P. (2020). Electoral Distancing: Alternatif Penyelenggaraan Pemilihan Kepala Daerah 2020 Ditengah Covid-19 Di Indonesia. Magistrorum Et Scholarium: Jurnal Pengabdian Masyarakat, 1 (1), 112121, DOI: https://doi.org/10.24246/jms.v1i12020p112-121.

Jayanti, D.A., Utami, D., Anggraeni, S., Izudin, A., \& Hadiarto, R. (2021). Pencegahan Dan Edukasi Covid-19 Di Wilayah Puskesmas Pasar Ambon. Jurnal Kreativitas Pengabdian Kepada Masyarakat (PKM), 4 (1), 188-194, DOI: https://doi.org/10.33024/jkpm.v4i1.3680.

Moudy, J., \& Syakurah, R. (2020). Hubungan Pengetahuan terkait Usaha Pencegahan Coronavirus Disease 2019 (COVID-19) di Indonesia. HIGEIA (Journal of Public Health Research and Development), 4(3), 333-346. https: / / doi.org/10.15294/higeia.v4i3.37844.

Spinelli, A. (2020). Menyelenggarakan Pemilu Di Tengah Pandemi COVID-19: Ujian Krusial Republik Korea. International Institute for Democracy and Electoral Assistance (International IDEA), 1-8, https://doi.org/10.31752/idea.2020.17.

Shalahuddin, I., Rosidin, U., \& Purnama, D. (2021). Edukasi Pada Masyarakat Desa Mekarbakti Kecamatan Pamulihan Kabupaten Sumedang Tentang Pentingnya Upaya-Upaya Pencegahan Penularan Penyakit Covid-19. Jurnal Kreativitas Pengabdian Kepada Masyarakat (PKM), 4 (1), 1 9, https://doi.org/10.33024/jkpm.v4i1.3594.

Smith, A.W., \& Freedman, D.O. (2020). Isolation, quarantine, social distancing and community containment: pivotal role for oldstyle public health measures in the novel coronavirus $(2019 \mathrm{nCoV})$ outbreak. Journal of Travel Medicine, 27 (2), taaa020, DOI: https: / /doi.org/10.1093/jtm/taaa020.

Ristyawati, A. (2020). Efektivitas Pelaksanaan Pilkada Serentak 2020 Pada Masa Pandemi Darurat Covid-19 Di Indonesia. Jurnal Crepido, 2 (2), 8596, DOI: https://doi.org/10.14710/crepido.2.2.85-96.

World Health Organization. Responding to community spread of COVID-19. https://www. who.int/publications/i/item/responding-to-communityspread-of-covid-19. (Diakses November 12, 2020).

Wulandari, A., Rahman, F., Pujianti, N., Sari, A.N., Laily, N., Anggraini, N., Mudin, F.I., Ridwan, A.M., Anhar, V.Y., Azmiyannor, M., \& Prasetio, D.B. (2020). Hubungan Karakteristik Individu dengan Pengetahuan tentang Pencegahan Coronavirus Disease 2019 pada Masyarakat di Kalimantan Selatan. Jurnal Kesehatan Mayarakat Indonesia. 15(1), 42-46, DOI: https://doi.org/10.26714/jkmi.15.1.2020.42-46. 